\title{
Modulation of N-nitrosomethylbenzylamine bioactivation by diallyl sulfide in vivo
}

\author{
Ludeke, Barbara I ; Dominé, Frédéric ; Ohgaki, Hiroko ; Kleihues, Paul
}

\begin{abstract}
Diallyl sulfide (DAS), a major component of garlic oil, is an inhibitor of tumorigenesis by various metabolcally activated carcinogens. In rats, pretreatment with DAS has been observed to suppress completely the induction of oesophageal neoplasms by N-nitrosomethylbenzylamine (NMBzA) (Wargovich et al. (1988) Cancer Res., 48, 6872-6875). This communication reports the effects of DAS on overall NMBzA metabolism and on DNA methylation of NMBzA in vivo under conditions equivalent to a single treatment of the chemoprevention assay. Male Fischer 344 rats received a single i.g. dose of DAS (200 mg/kg body wt) followed by an s.c. injection of [methyl-14C]NMBzA (3.5 mg/kg). In controls, exhalation of $14 \mathrm{CO} 2$ was complete within $5 \mathrm{~h}\left(\mathrm{t}^{1} / 2 \max =1.2 \mathrm{~h}\right)$. with $50 \%$ of the injected radioactivity recovered as 14CO2. When DAS was given $3 \mathrm{~h}$ prior to [methyl-14C]NMBzA, $49 \%$ of the injected radioactivity was released within $10 \mathrm{~h}\left(\mathrm{t}^{1} / 2 \max =3 \mathrm{~h}\right)$. When DAS was administered $18 \mathrm{~h}$ before the carcinogen, $42 \%$ of [methyl-14C]NMBzA was converted to $14 \mathrm{CO} 2$, with exhalation complete after $6 \mathrm{~h}$ $\left(\mathrm{t}^{1} \frac{2}{2} \max =1.8 \mathrm{~h}\right)$. We further examined the effects of acute doses of $10-200 \mathrm{mg} / \mathrm{kg}$ of DAS on DNA methylation by a single dose of NMBzA (3.5 mg/kg; survival time, $6 \mathrm{~h}$ ) administered $3 \mathrm{~h}$ later. At 200 $\mathrm{mg} / \mathrm{kg}$, DAS inhibited the formation of O6-methyldeoxyguanosine (O6-MEdG) in oesophagus (-26\%), nasal mucosa $(-51 \%)$, trachea $(-68 \%)$ and lung $(-78 \%)$. In liver, levels of $7-\mathrm{MEdG}$ were reduced by $43 \%$. Decreases in DNA methylation were proportional to dose for $>25 \mathrm{mg} / \mathrm{kg}$ of DAS in oesophagus, liver and nasal mucosa, for $25-200 \mathrm{mg} / \mathrm{kg}$ in trachea and $10-50 \mathrm{mg} / \mathrm{kg}$ in lung. The dose activity relationship for inhibition by DAS of DNA methylation by NMBzA suggests that short-term modulation of carcinogen bioactivation in situ contributes to but may not be sufficient for the chemoprevention of nitrosamine tumorigenesis by DAS. Diallyl sulfide (DAS), a major component of garlic oil, is an inhibitor of tumorigenesis by various metabolcally activated carcinogens. In rats, pretreatment with DAS has been observed to suppress completely the induction of oesophageal neoplasms by N-nitrosomethylbenzylamine (NMBzA) (Wargovich et al. (1988) Cancer Res., 48, 6872-6875). This communication reports the effects of DAS on overall NMBzA metabolism and on DNA methylation of NMBzA in vivo under conditions equivalent to a single treatment of the chemoprevention assay. Male Fischer 344 rats received a single i.g. dose of DAS (200 mg/kg body wt) followed by an s.c. injection of [methyl-14C] NMBzA (3.5 mg/kg). In controls, exhalation of $14 \mathrm{CO} 2$ was complete within $5 \mathrm{~h}\left(\mathrm{t}^{1} \frac{1}{2} \mathrm{max}=1.2 \mathrm{~h}\right)$. with $50 \%$ of the injected radioactivity recovered as $14 \mathrm{CO} 2$. When DAS was given $3 \mathrm{~h}$ prior to [methyl-14C]NMBzA, $49 \%$ of the injected radioactivity was released within $10 \mathrm{~h}\left(\mathrm{t}^{1} / 2 \max =3 \mathrm{~h}\right)$. When DAS was administered $18 \mathrm{~h}$ before the carcinogen, $42 \%$ of [methyl-14C]NMBzA was converted to $14 \mathrm{CO} 2$, with exhalation complete after 6 $\mathrm{h}\left(\mathrm{t}^{1 / 2} \mathrm{max}=1.8 \mathrm{~h}\right)$. We further examined the effects of acute doses of $10-200 \mathrm{mg} / \mathrm{kg}$ of DAS on DNA methylation by a single dose of NMBzA $(3.5 \mathrm{mg} / \mathrm{kg}$; survival time, $6 \mathrm{~h})$ administered $3 \mathrm{~h}$ later. At 200 $\mathrm{mg} / \mathrm{kg}$, DAS inhibited the formation of O6-methyldeoxyguanosine (O6-MEdG) in oesophagus (-26\%), nasal mucosa $(-51 \%)$, trachea $(-68 \%)$ and lung $(-78 \%)$. In liver, levels of $7-\mathrm{MEdG}$ were reduced by $43 \%$. Decreases in DNA methylation were proportional to dose for $>25 \mathrm{mg} / \mathrm{kg}$ of DAS in oesophagus, liver and nasal mucosa, for $25-200 \mathrm{mg} / \mathrm{kg}$ in trachea and $10-50 \mathrm{mg} / \mathrm{kg}$ in lung. The dose -activity relationship for inhibition by DAS of DNA methylation by NMBzA suggests that short-term modulation of carcinogen bioactivation in situ contributes to but may not be sufficient for the chemoprevention of nitrosamine tumorigenesis by DAS
\end{abstract}


DOI: https://doi.org/10.1093/carcin/13.12.2467

Posted at the Zurich Open Repository and Archive, University of Zurich ZORA URL: https://doi.org/10.5167/uzh-154128

Journal Article

Published Version

Originally published at:

Ludeke, Barbara I; Dominé, Frédéric; Ohgaki, Hiroko; Kleihues, Paul (1992). Modulation of N-nitrosomethylbenzylamine bioactivation by diallyl sulfide in vivo. Carcinogenesis, 13(12):2467-2470.

DOI: https://doi.org/10.1093/carcin/13.12.2467 


\section{SHORT COMMUNICATION}

\section{Modulation of $N$-nitrosomethylbenzylamine bioactivation by diallyl sulfide in vivo}

\author{
Barbara I.Ludeke, Frédéric Dominé, Hiroko Ohgaki \\ and Paul Kleihues
}

Institute of Neuropathology, Department of Pathology, University of Zürich, CH-8091 Zürich, Switzerland

Diallyl sulfide (DAS), a major component of garlic oll, is an inhibitor of tumorigenesis by various metabolically activated carcinogens. In rats, pretreatment with DAS has been observed to suppress completely the induction of oesophageal neoplasms by $N$-nitrosomethylbenzylamine (NMBzA) (Wargovich et al. (1988) Cancer Res., 48, 6872-6875). This communication reports the effects of DAS on overall NMBzA metabolism and on DNA methylation of NMBzA in vivo under conditions equivalent to a single treatment of the chemoprevention assay. Male Fischer 344 rats received a single i.g. dose of DAS ( $200 \mathrm{mg} / \mathrm{kg}$ body wt) followed by an s.c. injection of [methyl- $\left.{ }^{14} \mathrm{C}\right] \mathrm{NMBzA}(3.5 \mathrm{mg} / \mathrm{kg})$. In controls, exhalation of ${ }^{14} \mathrm{CO}_{2}$ was complete within $5 \mathrm{~h}$ $\left(t_{1 / 2 \max }=1.2 \mathrm{~h}\right)$, with $50 \%$ of the injected radioactivity recovered as ${ }^{14} \mathrm{CO}_{2}$. When DAS was given $3 \mathrm{~h}$ prior to [methyl- ${ }^{14} \mathrm{C}$ ] NMBzA, $49 \%$ of the injected radioactivity was released within $10 \mathrm{~h}\left(t_{1 / 2 \max }=3 \mathrm{~h}\right)$. When DAS was administered $18 \mathrm{~h}$ before the carcinogen, $42 \%$ of [methyl- ${ }^{14} \mathrm{C}$ ]NMBzA was converted to ${ }^{14} \mathrm{CO}_{2}$, with exhalation complete after $6 \mathrm{~h}\left(t_{1 / 2 \max }=1.8 \mathrm{~h}\right)$. We further examined the effects of acute doses of $10-200 \mathrm{mg} / \mathrm{kg}$ of DAS on DNA methylation by a single dose of $\mathrm{NMBzA}(3.5 \mathrm{mg} / \mathrm{kg}$; survival time, $6 \mathrm{~h}$ ) administered $3 \mathrm{~h}$ later. At $200 \mathrm{mg} / \mathrm{kg}$, DAS inhibited the formation of $\boldsymbol{O}^{6}$-methyldeoxyguanosine $\left(O^{6}-\mathrm{MEdG}\right)$ in oesophagus $(-26 \%)$, nasal mucosa $(-51 \%)$, trachea (-68\%) and lung (-78\%). In liver, levels of 7-MEdG were reduced by $43 \%$. Decreases in DNA methylation were proportional to dose for $>25 \mathrm{mg} / \mathrm{kg}$ of DAS in oesophagus, liver and nasal mucosa, for $25-200 \mathrm{mg} / \mathrm{kg}$ in trachea and $10-50 \mathrm{mg} / \mathrm{kg}$ in lung. The dose-activity relationship for inhibition by DAS of DNA methylation by NMBzA suggests that short-term modulation of carcinogen bioactivation in situ contributes to but may not be sufficient for the chemoprevention of nitrosamine tumorigenesis by DAS.

Diallyl sulfide (DAS*), a major flavour and fragrance component of garlic oil (1), has been shown to be an effective inhibitor of tumorigenesis by diverse metabolically activated chemical carcinogens (2-5). In the most striking example of chemoprevention, Wargovich and co-workers reported (4) that pretreatment with DAS completely prevented the formation in rat oesophagus of both malignant and premalignant lesions by $N$-nitrosomethylbenzylamine (NMBzA), an exceptionally potent and selective oesophageal carcinogen in this species (6). After preadministration of DAS, a significant reduction has been observed in nuclear aberrations induced by NMBzA and dimethylhydrazine $(4,7)$ but not in the nucleotoxicity of the direct-acting methylating

*Abbreviations: DAS, diallyl sulfide; NMBzA, $N$-nitrosomethylbenzylamine; $O^{6}$-MEdG, $O^{6}$-methyldeoxyguanosine, 7-MEdG, 7-methyldeoxyguanosine.

(C) Oxford University Press carcinogens $N$-nitrosomethylurea and $N$-methyl- $N^{\prime}$-nitro- $N$ nitrosoguanidine (7). Studies in vitro have shown that DAS also is an inhibitor of oxidative metabolism by cytochrome P450 enzymes of a number of carcinogenic nitrosamines, including NMBzA, $N$-nitrosodimethylamine, $N$-nitrosodiethylamine and 4-( $N$-methyl- $N$-nitrosamino)-1-(3-pyridyl)-1-butanone $(4,8-10)$. These findings suggested that DAS may block nitrosamineinduced tumorigenesis by inhibiting nitrosamine bioactivation in situ. In the present investigation, we have examined this possibility by assessing the effects of DAS on the overall metabolism of NMBzA and on DNA methylation by NMBzA in viw.

In the protocol developed by Wargovich and co-workers (4), rats received five weekly treatments consisting of an i.g. dose of $200 \mathrm{mg} / \mathrm{kg}$ of DAS followed $3 \mathrm{~h}$ later by a s.c. injection of $3.5 \mathrm{mg} / \mathrm{kg}$ of NMBzA. However, in vitro demethylation of NMBzA was significantly lower by hepatic microsomes prepared $18 \mathrm{~h}$ after a similar dose of DAS than by microsomes collected $3 \mathrm{~h}$ post-treatment (8). In order to determine whether there is a similar difference in viwo between immediate and delayed effects of DAS on overall NMBzA metabolism, we monitored the formation of ${ }^{14} \mathrm{CO}_{2}$ and radioactive urinary metabolites from [methyl- ${ }^{14} \mathrm{C}$ ]NMBzA administered 3 or $18 \mathrm{~h}$ after a single dose of DAS. In addition, we determined the dose-activity relationship of the effects of DAS on NMBzA bioactivation in target and non-target tissues under conditions equivalent to a single treatment of the chemoprevention experiment (4).

[methyl- ${ }^{14} \mathrm{C}$ ] NMBzA was synthesized according to Skipper (11). The radiochemical purity was $83 \%$. DAS was obtained from Aldrich Chemical Co. (Milwaukee, WI). All other chemicals and reagents were purchased from commercial sources described earlier (12).

Young male Fischer 344 rats $(100-140 \mathrm{~g}$ body wt) were obtained from Charles River Wiga GmbH, D-8741 Sulzfeld (Germany) and maintained on a standard laboratory diet with tap water ad libitum. For determination of overall NMBzA metabolism, three pairs of rats were treated with an i.g. dose ( $1 \mathrm{ml} / 140 \mathrm{~g}$ ) of corn oil (pair 1) or $200 \mathrm{mg} / \mathrm{kg}$ of DAS in corn oil (pairs 2 and 3), followed after $3 \mathrm{~h}$ (pairs 1 and 2) or $18 \mathrm{~h}$ (pair 3) by a single s.c. injection of [methyl- ${ }^{14} \mathrm{C}$ ]NMBzA (3.5 $\mathrm{mg} / \mathrm{kg} ; 0.49 \mathrm{mCi} / \mathrm{mmol})$. Immediately thereafter, the animals were placed in a metabolic cage (Jencons Metabowl, Hemel Hempstead, UK). Exhaled ${ }^{14} \mathrm{CO}_{2}$ was absorbed in two serially connected Nilox columns, each containing $600 \mathrm{ml}$ of $1 \mathrm{M} \mathrm{NaOH}$ (13). Samples $(0.5 \mathrm{ml})$ were collected hourly. Radioactivity was determined by liquid scintillation counting (efficiency, $87.4 \%$ ) after the addition of $0.5 \mathrm{ml}$ of $5 \mathrm{M} \mathrm{NaOH}$ and $10 \mathrm{ml}$ of Hionic Fluor (Packard Instruments, Zurich, Switzerland).

For studies on DNA methylation, groups of six rats were given a single dose of $0,10,25,50,100$ or $200 \mathrm{mg} / \mathrm{kg}$ of DAS in corn oil (p.o., $1 \mathrm{ml} / 140 \mathrm{~g}$ ), followed after $3 \mathrm{~h}$ by a single s.c. injection of NMBzA $(3.5 \mathrm{mg} / \mathrm{kg})$. Animals were killed by exsanguination under ether anaesthesia $6 \mathrm{~h}$ later. Tissues were pooled (oesophagus, trachea, nasal cavity scrapings) or collected individually (livers, lungs, kidneys), rapidly frozen in liquid 


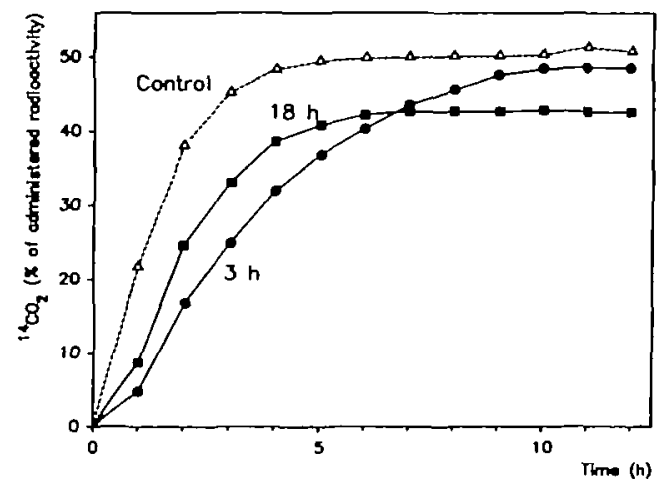

Fig. 1. Effects of DAS on the formation of ${ }^{14} \mathrm{CO}_{2}$ from $N$-nitroso [methyl $-{ }^{14} \mathrm{C}$ ]benzylamine. Animals received an i.g. dose $(1 \mathrm{ml} / 140 \mathrm{~g}$ body wt) of com oil (controls) or $200 \mathrm{mg} / \mathrm{kg}$ of DAS in corn oil 3 or $18 \mathrm{~h}$ prior to a single s.c. injection of $N$-nitroso[methyl- $\left.{ }^{14} \mathrm{C}\right]$ benzylamine $(3.5 \mathrm{mg} / \mathrm{kg}$; $0.49 \mathrm{mCi} / \mathrm{mmol}$ ). Data are plotted as cumulative percentages of the total radioactivity administered.

nitrogen and stored at $-70^{\circ} \mathrm{C}$. DNA was isolated by automated phenolic extraction using a Model 340A Nucleic Acid Extractor (Applied Biosystems, Inc., Foster City, CA) as described previously (12), except that tissue homogenates were filtered through nylon gauze ( $30 \mu \mathrm{m}$ mesh; Willi Fischer Labortechnik, Frankfurt/Main, Germany). Methylated deoxyguanosines were quantitated by immuno-slot-blot assays using rabbit antiserum NPZ-193 to $O^{6}$-methyldeoxyguanosine $\left(O^{6}-\mathrm{MEdG}\right)(14)$ and an antiserum to imidazole ring-opened 7-methyldeoxyguanosine (7-MEdG) (15) essentially as described elsewhere (16), with the following modifications. DNA denaturation and conversion of 7-MEdG to the imidazole ring-opened form were carried out at alkaline pH. Briefly, DNA $(12 \mu \mathrm{g}$ in $200 \mu \mathrm{l}$ of $1 \mathrm{mM}$ EDTA/10 mM Tris, pH 7.8) was treated with $200 \mu 1$ of $100 \mathrm{mM}$ $\mathrm{NaOH}$ at room temperature for $10 \mathrm{~min}$, neutralized by the addition of $200 \mu$ l of $15 \%(\mathrm{v} / \mathrm{v})$ acetic acid, and immediately mixed with $200 \mu \mathrm{l}$ of $4 \mathrm{M}$ ammonium acetate. Concentrations of methylated deoxyguanosines were calculated using peak areas of the densitometric evaluation. The limits of detection for $\sigma^{6}-\mathrm{MEdG}$ and 7-MEdG were 0.8 and $7.5 \mu \mathrm{mol} / \mathrm{mol} \mathrm{dG} \mathrm{respec}-$ tively.

Modulation of the overall metabolism of a single dose $(3.5$ $\mathrm{mg} / \mathrm{kg}$ ) of [methyl $-{ }^{14} \mathrm{C}$ ] NMBzA by a preceding acute dose of DAS $(200 \mathrm{mg} / \mathrm{kg})$ is shown in Figure 1 . In controls, exhalation of ${ }^{14} \mathrm{CO}_{2}$ was complete within $5 \mathrm{~h}$, with $50 \%$ of the injected radioactivity recovered as ${ }^{14} \mathrm{CO}_{2}$; half of the total amount of exhaled ${ }^{14} \mathrm{CO}_{2}$ was released within $1.2 \mathrm{~h}\left(t_{1 / 2 \max }\right)$. Both the rate and the extent of conversion of [methyl- $\left.{ }^{14} \mathrm{C}\right] \mathrm{NMBzA}$ to ${ }^{14} \mathrm{CO}_{2}$ were almost identical to those observed previously $(13,18)$. Recovery of radioactivity from urine after $12 \mathrm{~h}(20 \%$ of the total administered radioactivity) was slightly higher in the present experiment than reported previously (13), which could reflect the excretion of polar radiolysis products of [methyl- ${ }^{14} \mathrm{C}$ ]NMBzA. When [methyl- ${ }^{14} \mathrm{C}$ ]NMBzA was given $3 \mathrm{~h}$ after DAS, formation of ${ }^{14} \mathrm{CO}_{2}$ was markedly retarded, with a total of $49 \%$ of the administered radioactivity released within $10 \mathrm{~h}\left(t_{1 / 2 \max }=\right.$ $3 \mathrm{~h}$ ). In contrast, production of ${ }^{14} \mathrm{CO}_{2}$ from [methyl- ${ }^{4} \mathrm{C}$ ] NMBzA administered $18 \mathrm{~h}$ after DAS was complete within $6 \mathrm{~h}$ $\left(t_{1 / 2 \max }=1.8 \mathrm{~h}\right)$, whereas the fraction exhaled as ${ }^{14} \mathrm{CO}_{2}$ was decreased to $42 \%$. DAS had no effect on the excretion of radioactive urinary metabolites (data not shown).

As shown in Table I, administration of a single oral dose of DAS $(200 \mathrm{mg} / \mathrm{kg}) 3 \mathrm{~h}$ prior to an s.c. injection of NMBzA (3.5 $\mathrm{mg} / \mathrm{kg}$; survival time, $6 \mathrm{~h}$ ) led to decreases in the formation of
Table I. Effects of a single high dose of DAS on DNA methylation by NMBzA in various rat tissues

\begin{tabular}{llll}
\hline & Corn oil & DAS & Decrease (x) \\
\hline$O^{6}$-MEdG & & & \\
Oesophagus & $8.4 \pm 1.4^{\mathrm{b}}$ & $6.2 \pm 0.1$ & 26 \\
Nasal cavity & $9.6 \pm 1.0$ & $3.4 \pm 0.1$ & 51 \\
Trachea & 9.1 & $2.9 \pm 0.4$ & 68 \\
Lung & $3.2 \pm 0.4$ & $0.7 \pm 0.4$ & 78 \\
Liver & $2.4 \pm 0.6$ & $2.0 \pm 0.6$ & 0 \\
Kidney & $1.8 \pm 0.6$ & $2.1 \pm 0.7$ & 0 \\
& & & \\
7-MedG & & 58.2 & 30 \\
Oesophagus & 83.8 & $21.8 \pm 6.6$ & 43 \\
Liver & $38.5 \pm 0.1$ & \\
\hline
\end{tabular}

'Adult male Fischer 344 rats received a single dose by gavage $(1 \mathrm{ml} / 140 \mathrm{~g}$ body wt) of either corn oil or $200 \mathrm{mg} / \mathrm{kg}$ of DAS in corn oil, followed $3 \mathrm{~h}$ later by an s.c. injection of NMBzA $(3.5 \mathrm{mg} / \mathrm{kg}$; survival time, $6 \mathrm{~h})$. ${ }^{b} \mu \mathrm{mol} / \mathrm{mol}$ deoxyguanosine. Values are expressed as mean $\pm \mathrm{SD}$ of five animals assessed individually (liver, lung, kidney; $n=3-12$ ) or of DNA pooled from five animals (oesophagus, nasal mucosa, trachea; $n=3-6$ ).

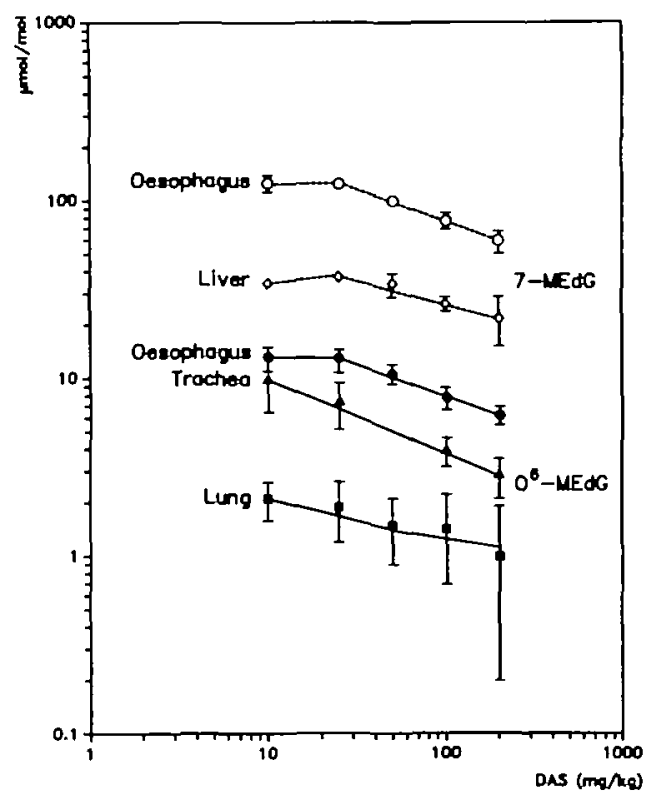

Fig. 2. Dose-dependent inhibition by DAS of DNA methylation by $N_{M} B_{z} A$ in various rat tissues. Animals received a single i.g. dose $(1 \mathrm{ml} / 140 \mathrm{~g}$ body wt) of $10-200 \mathrm{mg} / \mathrm{kg}$ of DAS in corn oil, followed $3 \mathrm{~h}$ later by a s.c. injection of $\mathrm{NMB}_{z} \mathrm{~A}(3.5 \mathrm{mg} / \mathrm{kg})$. Concentrations of methylated

deoxyguanosines were determined $6 \mathrm{~h}$ after administration of the carcinogen. Results are expressed as $\mu \mathrm{mol} / \mathrm{mol}$ deoxyguanosine. Each point represents mean \pm SD of determinations in DNA from two animals (liver; $n=3-12$ ) or five animals (lung; $n=3-12$ ) assessed individually or in DNA pooled from five anımals (oesophagus, trachea; $n=3-6$ ).

$O^{6}-\mathrm{MEdG}$ in oesophagus (-26\%), nasal mucosa (-51\%), trachea $(-68 \%)$ and lung $(-78 \%)$. In liver, concentrations of $\sigma^{6}$-MEdG were close to the limit of quantitation and a significant effect of DAS on its formation was not observed; however, levels of 7-MEdG were decreased by $43 \%$. DAS did not have a detectable effect on DNA methylation in kidney. Dose-activity curves are shown in Figure 2. In liver and oesophagus, inhibition of DNA methylation was directly proportional to dose for $>25 \mathrm{mg} / \mathrm{kg}$ of DAS. Similar results were obtained in nasal mucosa (data not shown). Trachea was more sensitive to the inhibitory effects of low doses of DAS, with a dose-dependent decrease in the formation of $\sigma^{6}$-MEdG observed for $25-200$ 
$\mathrm{mg} / \mathrm{kg}$. In lung, there was a significant $(P<0.001)$ trend towards lower levels of methylation with higher doses of DAS for doses ranging from 10 to $50 \mathrm{mg} / \mathrm{kg}$. The linear portions of the double-logarithmic dose-activity curves were parallel in all tissues.

Differential modulation of cytochrome P450 enzyme levels has been proposed to be one of several mechanisms underlying chemoprevention of nitrosamine tumorigenesis by DAS. In rat liver, induction of cytochrome P4502B1, and of ethoxyresorufin and pentoxyresorufin dealkylase activities was detected $5 \mathrm{~h}$ after DAS administration, with maximum levels attained within $48 \mathrm{~h}$ $(8,9)$. Conversely, preadministration with DAS has been shown to result in inactivation and subsequent removal from the microsomal membrane of hepatic cytochrome P4502E1 within $18 \mathrm{~h}(8,9)$. We observed a decrease in both the extent and rate of formation of ${ }^{14} \mathrm{CO}_{2}$ from [methyl ${ }^{14} \mathrm{C}$ ]NMBzA given $18 \mathrm{~h}$ after a single dose of DAS, suggesting that a significant reduction of nitrosamine bioactivation may be achieved after repeated administrations of DAS through modulation of cytochrome $\mathbf{P 4 5 0}$ enzyme levels in target cells. However, although NMBzA is preferentially bioactivated in the oesophageal mucosa, measurements of overall metabolism in the intact animal primarily reflect hepatic turnover because of the size of the liver $(17,18)$ and cannot necessarily be extrapolated to other organs. Little is known on the effects of DAS on monooxygenase concentrations in extrahepatic tissues. In nasal microsomes, concentrations of P4502E1 and proteins immunochemically related to P4502BI were not affected by pretreatment with DAS (10). The effects of DAS on cytochrome P450 levels in oesophagus have not yet been reported. Stimulation of hepatic nitrosamine metabolism by chronic administration of DAS could indirectly contribute to chemoprevention of nitrosamine tumorigenesis in other tissues even in the absence of an effect on extrahepatic cytochrome P450 levels by increasing first-pass clearance of nitrosamines by the liver and hence reducing extrahepatic concentrations.

Other potentially anticarcinogenic long-term effects of DAS that are not directly related to carcinogen bioactivation have been described. Induction of phase II detoxification enzymes by DAS $(2,19,20)$, could limit the mutagenicity of a wide range of carcinogens by stimulating conjugation and excretion of reactive intermediates. In the present study, formation of urinary metabolites from NMBzA was not significantly altered by an acute dose of DAS administered either 3 or $18 \mathrm{~h}$ earlier. However, there is evidence that induction of detoxification pathways may take longer. In mice, hepatic glutathione S-transferase activity was increased from $118 \%$ of control levels at $24 \mathrm{~h}$ to $178 \%$ at $48 \mathrm{~h}$ after DAS administration (21). DAS has further been shown to inhibit the induction of ornithine decarboxylase by carcinogens (22) and $\gamma$-irradiation (23). Suppression of the proliferative response to genotoxic damage by this or related mechanisms has been proposed to partly account for the decrease in tumour progression (24), in phorbol ester-induced promotion $(25,26)$, and in the tumorigenesis of metabolically activated and direct-acting carcinogens (27) which were observed when DAS or garlic extracts were administered postinitiation.

In vitro studies have revealed that DAS is a competitive inhibitor of cytochrome P4502E1 (8). Our finding that the rate of ${ }^{14} \mathrm{CO}_{2}$ production from [methyl- ${ }^{14} \mathrm{C}$ ]NMBzA was markedly decreased when DAS was given $3 \mathrm{~h}$ before the carcinogen but only marginally affected when DAS was administered $18 \mathrm{~h}$ prior to NMBzA suggests that nitrosamine metabolism in viwo is inhibited by DAS itself or short-lived early metabolite(s). It has recently been demonstrated (28) that DAS is completely metabolized within $18 \mathrm{~h}$ in vivo. Metabolites include diallyl sulfoxide, a competitive inhibitor of hepatic cytochrome P4502E1 in vitro, and diallyl sulfone, which has been reported to rapidly inactivate cytochrome P4502E1 via competitive suicide inhibition (28). The time course of ${ }^{14} \mathrm{CO}_{2}$ exhalation has previously been shown to closely parallel the overall metabolism of ${ }^{14} \mathrm{C}$ labelled nitrosamines $(17,29)$. However, modulation by DAS of enzyme activities involved in the metabolism of the $\mathrm{Cl}$ pool may have additionally inhibited the release of ${ }^{14} \mathrm{CO}_{2}$.

Pretreatment with DAS led to dose-dependent inhibition of DNA methylation by NMBzA in various rat tissues over a wide range of doses. Nevertheless, DAS was not a very potent inhibitor of NMBzA bioactivation. At the highest dose of DAS tested ( $200 \mathrm{mg} / \mathrm{kg}$ ), decreases in the extent of DNA methylation ranged from $26 \%$ in oesophagus to $78 \%$ in lung (Table I). Levels of methylated deoxyguanosines in oesophagus were thus only moderately reduced when DAS and NMBzA were administered at the same time interval and dose ratio at which, after repeated applications, the development of preneoplastic and neoplastic lesions was completely prevented (4). The partial inhibition of NMBzA bioactivation is tantamount to a decrease in the effective dose of NMBzA. It has been shown (6) that even at very small doses of genotoxic carcinogens, there is a clear dose-effect and time relationship for tumor induction, which can be expressed as follows:

$$
d \cdot t^{n}=\text { constant; } n>1
$$

with $d$ being the daily dose, $t$ the median tumour latency period and $n$ representing carcinogenic potency. Therefore, short-term inhibition by DAS of NMBZA bioactivation would be expected to significantly delay but not to prevent tumour induction by NMBzA using the treatment protocol of the chemoprevention assay. However, the possibility remains that multiple doses of DAS could severely reduce the capacity for nitrosamine bioactivation in this tissue if pretreatment with DAS resulted in cumulative and persistent inactivation of oesophageal cytochrome P450 isozymes as a consequence of slow repair or replacement. In the chemoprevention experiments, animals were killed 15 weeks after the first treatment (4). Conceivably, NMBzA-induced oesophageal neoplasms might have been detected had the observation period been extended to account for the increased latency period arising from damage incurred during the initial treatment and the decreased effective dose of carcinogen during subsequent administrations.

In summary, our results strongly s.ggest that the extent to which NMBzA bioactivation in the oesophagus was inhibited by the immediately preceding dose of DAS during each treatment cycle was not sufficient to elicit the complete suppression of oesophageal tumorigenesis observed in long-term carcinogenicity assays (4). Inhibition of bioactivation is thus very likely only one of multiple mechanisms involved in the suppression of nitrosamine tumorigenesis by DAS. Preliminary investigations have suggested that at low doses of DAS, modulation of cellular responses to genotoxic damage may predominate over effects on carcinogen metabolism (5). This aspect of the chemopreventive properties of DAS may be particularly relevant to human cancer in view of the recent epidemiological study linking consumption of allium vegetables to a reduced incidence of gastric cancer (30).

\section{Acknowledgements}

We would like to thank Ms Isabelle Cackett for expert tectunical assistance, and Dr Chris Wild, International Association for Research on Cancer, Lyon, France, for his kind gift of the antiserum to 7-methyldeoxyguanosine. This work was supported by the Swiss National Science Foundation. 


\section{References}

1. Brodnitz,M.H., Pascale,J.V. and Derslice,L.V. (1971) Flavor components of garlic extract. J. Agric. Food Chem., 19, 273-275.

2. Sparnins,V.L., Barany,G. and Wattenberg,L.W. (1988) Effects of organosulfur compounds from garlic and onions on benzo[a]pyrene-induced nooplasia and glutathione S-transferase activity in the mouse. Cancinogenesis, 9, $131-134$.

3. Wargovich,M.J. (1987) Diallyl sulfide, a flavor component of garlic (Allium sativum), inhibits dimethylhydrazine-inatuced colon cancer. Carcinogenesis, 8, 487-489.

4. Wargovich,M.J., Woods,C., Eng,V.W.S., Stephens,L.C. and Gray,K. (1988) Chemoprevention of $N$-nitrosomethylbenzylamine-induced esophageal cancer in rats by the naturally occurring thioether, diallyl sulfide. Cancer Res., 48, $6872-6875$.

5. Hayes,M.A., Rushmore,T.H. and Goldberg,M.T. (1987) Inhibition of hepatocarcinogenic responses to 1,2-dimethylhydrazine by diallyl sulfide, a component of garlic oil. Carcinogenesis, 8, 1155-1157.

6. Druckrey,H., Preussmann, R., Ivankovic,S. and Schmähl,D. (1967) Organotrope carcinogene Wirkangen bei 65 verschiedenen $N$-NitrosoVerbindungen an BD-Ratten. Z. Krebsforsch., 69, 103-201.

7. Wargovich,M.J. and Goldberg,M.T. (1985) Diallyl sulfide: a naturally occurring thioether that inhibits carcinogen-induced nuclear damage to colon epithelval cells in viro. Mutat. Res., 143, 127-129.

8. Brady,J.F., Li,D., Lshizaki,H. and Yang,C.S. (1988) Effect of diallyl sulfide on rat liver microsomal nitrosamine metabolism and other monooxygenase activities. Cancer Res., 48, 5937-5940.

9. Brady,J.F., Wang,M.-H., Hong,J.-Y., Xiao,F., Li,Y., Yo,J.-S.H., Ning,S.M., Lee,M.-J., Fakuto,J.M., Gapac,J.M. and Yang,C.S. (1991) Modulation of rat hepatic microsomal monooxygenase enzymes and cytotoxicity by diallyl sulfide. Toxicol. Appl. Pharmacol., 108, 342-354.

10. Hong,J.-Y., Smuth,T., Lee,M.-J., Li,W., Ma,B.-L., Ning,S.M., Brady,J.F., Thomas,P.E. and Yang,C.S. (1991) Metabolism of carcinogenic nitrosamines by rat nasal mucosa and the effect of diallyl sulfide. Cancer Res., 51, $1509-1514$.

11. Skipper,P. (1978) Synthesis of ${ }^{14} \mathrm{C}$-methylbenzylnitrosamine and methyl- ${ }^{14} \mathrm{C}$ benzylnitrosamine. J. Labelled Compd. Radiopharmaceut., 15, 575-579.

12. Ji,C., Ludeke,B.I., Kleihues,P. and Wiessler,M. (1991) DNA methylation in various rat tissues by the esophageal carcinogen $N$-nitrosomethyl-n-arylamine and six of its positional isomers. Chem. Res. Toxical., 4, 77-81.

13. Hodgson,R.M., Schweinsberg,F., Wiessler,M. and Kleihues,P. (1982) Mechanism of esophageal tumor induction in rats by $N$-nitrosomethylbenzylamine and its ring-methylated analog $N$-nitrosomethyl(4-methylbenzyl)amine. Cancer Res., 42, 2836-2840.

14. Ludeke,B.I. and Kleihues,P. (1988) Formation and persistence of $O^{6}$-(2-hydroxyethyl)-2'-deoxyguanosine in DNA of various rat tissues following a single dose of $N$-nitroso- $N$-(2-hydroxyethyl)urea. An immunoslot-blot study. Carcinogenesis. 9, 147-151.

15. Degan,P., Montesano,R. and Wild,C.P. (1988) Antibodies against 7-methyldeoxyguanosine: its detection in rat peripheral blood lymphocyte DNA and potential applications to molecular epidemiology. Cancer Res., 48, $5065-5070$.

16. Ludeke,B., Meier,T. and Kleihues,P. (1991) Bioactivation of asymmetric $N$ dialkyl nitrosamines in rat tissues derived from the ventral entoderm. In O'Neill,I.K., Chen,J.S. and Bartsch,H. (eds), Relevance to Human Cancer of N-Nitroso Compounds, Tobacco Smokes and Mycotoxins, IARC Scientific Publication no. 105. International Agency for Research on Cancer, Lyon, pp. 286-293.

17. Hodgson,R.M., Wiessler,M. and Kleihues,P. (1980) Preferential methylation of target organ DNA by the oesophageal carcinogen $\mathrm{N}$ nitrosomethylbenzylamine. Carcinogenesis, 1, 861-866.

18. Wiestler,O.D., von Deimling,A., von Hofe,E., Schmerold,I., Wiestler,E. and Kleihues,P. (1987) Interorgan shift of nitrosamine metabolism by dietary ethanol. Arch. Toxicol., Suppl., 11, 53-65.

19. Maurya,A.K. and Singh,S.V. (1991) Differential induction of glutathione transferase isoenzymes of mice stomach by diallyl sulfide, a naturally occurring apticarcinogen. Cancer Lett., 57, 121-129.

20. Tadi,P.P., Teel,R.W. and Lau,B.H. (1991) Organosulfur compounds of garlic modulate mutagenesis, metabolism and DNA binding of aflatoxin B1. Nutr. Cancer, 15, 87-95.

21. Sumiyoshi,H. and Wargovich,M.J. (1990) Chemoprevention of 1,2-dimethylhydrazine-induced colon cancer in mice by naturally occurring organosulfur compounds. Cancer Res., 50, 5084-5087.

22. Hu,P.J. and Wargovich,M.J. (1989) Effect of diallyl sulfide on MNNGincuced nuclear aberrations and ornithine decarboxylase activity in the glandular stomach mucosa of the Wistar rat. Cancer Leth., 47, 153-158.

23. Baer, A.R. and Wargovich,M.J. (1989) Role of omithine decarboxylase in diallyl sulfide unhibition of colonic radiation injury in the mouse. Cancer Res., 49, $5073-5076$.

24. Wattenberg,L.W., Sparnins,V.L. and Barany,G. (1989) Inhibition of $N$ nitrosodiethylamine carcinogenesis in mice by naturally occurring organosulfur compounds and monoterpenes. Cancer Res., 49, 2689-2692.

25. Belman,S. (1983) Onion and garlic oils inhibit tumor promotion. Carcinogenesis, 4, 1063-1065.

26. Nishino,H., Iwashima,A., Itakura, Y., Matsuura,H. and Fuwa,T. (1989) Antitumor-promoting actuity of garlic extracts. Oncology, 46, 277-280.

27. Jang,J.J., Cho,K.J., Loe, Y.S. and Bae,J.H. (1991) Modifying responses of ally! sulfide, indole-3-carbinol and germanium in a rat multi-organ carcinogenesis model. Carcinogenesis, 12, 691-695.

28. Brady,J.F., Ishizaki,H., Fukuto,J.M., Lin,M.C., Fadel,A., Gapac,J.M. and Yang,C.S. (1991) Inhibition of cytochrome P-450 2E1 by diallyl sulfide and its metabolites. Chem. Res. Toxicol., 4, 642-647.

29. Swan,P.F. (1969) The rate of breakdown of methyl methanesulphonate, dimethyl sulphate and $N$-methyl- $N$-nitrosourea in the rat. Biochem. $J ., 110$, $49-52$.

30. You,W.-C., Blot,W.J., Chang,Y.-S., Ershow,A., Yang,Z.T., An,Q., Henderson,B.E., Fraumeni.J.F., Jr and Wang,T. -G. (1989) Allium vegetables and reduced risk of stomach cancer. J. Natl. Cancer Inst., 81, 162-164.

Received on March 23, 1992; revised on August 28, 1992; accepted on September 3. 1992 